\title{
Analisis Rasio Profitabilitas Dalam Memprediksi Pergerakan Harga Saham Pada Perusahaan LQ-45 Di BEI
}

\author{
Reva Maria Valianti ${ }^{1}$, Edduar Hendri ${ }^{2}$ \\ ${ }^{1}$ Akuntansi, Fakultas Ekonomi, Univ. PGRI Palembang, revavalianti@univpgri-palembang.ac.id \\ ${ }^{2}$ Manajemen, Fakultas Ekonomi, Univ. PGRI Palembang, hendriedduar71@univ.pgri-palembang.ac.id
}

\begin{abstract}
ABSTRAK
Tujuan penelitian ini mengetahui Pengaruh rasio profitabiltas Terhadap Harga Saham pada Perusahaan Indeks LQ-45 di Bursa Efek Indonesia. Populasi yang digunakan adalah seluruh perusahaan yang sahamnya tergabung dalam indeks LQ-45 sebanyak 45 Perusahaan. Sampel sebanyak 24 perusahaan yang dipilih secara purposive random sampling, yaitu perusahaan Indeks LQ-45 yang terdaftar di BEI periode tahun 2011-2016. Data laporan keuangan yang digunakan adalah laporan keuangan yang telah dipublikasikan di dalam Indonesia Capital Market Directory (ICMD) 2017. Alat analisis yang digunakan adalah uji asumsi klasik, kemudian dilanjutkan analisis regresi berganda, uji t, uji $\mathrm{F}$ dan koefisien determinasi.

Hasil penelitian menunjukkan bahwa variabel ROA, ROE dan NPM secara bersama-sama berpengaruh signifikan terhadap harga saham. Sedangkan secara parsial variabel ROA dan NPM berpengaruh signifikan terhadap harga saham. Sedangkan ROE berpengaruh tidak signifikan terhadap harga saham pada Perusahaan Indeks LQ-45 di BEI periode 2011-2016.
\end{abstract}

Kata Kunci : ROA, ROE, NPM dan Harga Saham

\section{ABSTRACT}

The purpose of this study is to know the effect of profitability ratios on stock prices on the LQ-45 Index Company in Indonesia Stock Exchange. The population used is all companies whose shares are incorporated in the $L Q-45$ index of 45 Companies. A sample of 24 companies selected by purposive random sampling, namely LQ-45 Index companies listed on the BEI period 2011-2016. The financial statements used are published financial statements in Indonesia Capital Market Directory (ICMD) 2017. The analysis tools used are classical assumption test, followed by multiple regression analysis, $t$ test, $F$ test and coefficient of determination.

The results showed that the variables ROA, ROE and NPM together have a significant effect on stock prices. While the partial ROA and NPM variables significantly affect the stock price. While ROE has no significant effect on stock price at LQ-45 Index Company in BEI period 2011-2016.

Keywords : ROA, ROE, NPM and Stock Price

\section{PENDAHULUAN}

Rasio profitabilitas merupakan

rasio untuk menilai kemampuan

perusahaan dalam mencari

keuntungan. Rasio ini juga memberikan ukuran tingkat efektivitas manajemen suatu perusahaan. Hal ini ditunjukan oleh laba yang dihasilkan dari penjualan dan pendapatan investasi. Intinya adalah penggunaan rasio ini menunjukkan efisiensi perusahaan (Kasmir, 2014:196).

Harga saham merupakan nilai saham di pasar atau yang biasa disebut dengan nilai pasar atau harga pasar yang berfluktuasi dari waktu ke waktu tergantung dari prospek perusahaan di masa yang akan datang. Harga saham merupakan cerminan keberhasilan manajemen perusahaan dalam menjalankan operasional perusahaan. Perusahaan yang memiliki kinerja baik akan memungkinkan sahamnya akan diminati oleh investor. Permintaan saham yang semakin meningkat mampu meningkatkan harga saham suatu perusahaan sehingga harga 
saham yang semakin meningkat dapat dijadikan indikator di dalam menganalisis kinerja keuangan perusahaan.

Dari sudut pandang investor, salah satu indikator penting untuk menilai prospek perusahaan di masa datang adalah dengan melihat sejauhmana kemampuan perusahaan menghasilkan laba yang bisa diperoleh pemegang saham yang berasal dari aset-aset yang dimiliki perusahaan. Dalam penelitian ini memfokuskan pada rasio profitabilitas yaitu hanya pada rasio ROA, ROE dan NPM.

Berikut disajikan data mengenai rata-rata ROA, ROE, NPM dan harga saham pada perusahaan Indeks LQ-45 di Bursa Efek Indonesia selama periode 2011-2016 yang dapat dilihat pada grafik berikut :

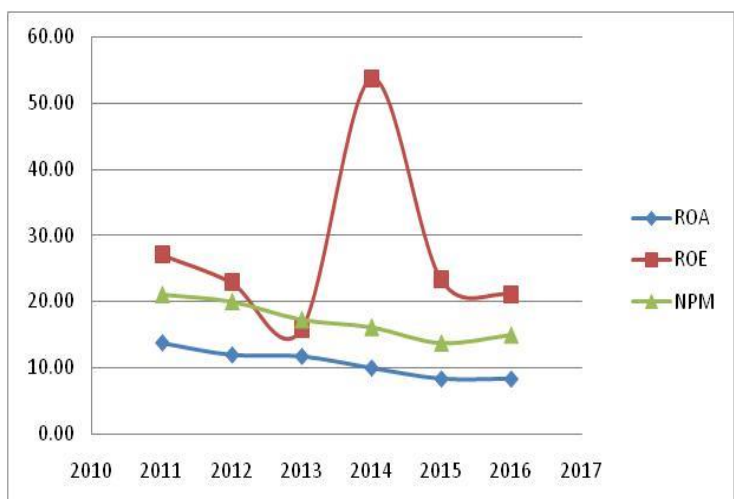

Gambar 1. Perkembangan Rata-Rata ROA, ROE, dan NPM

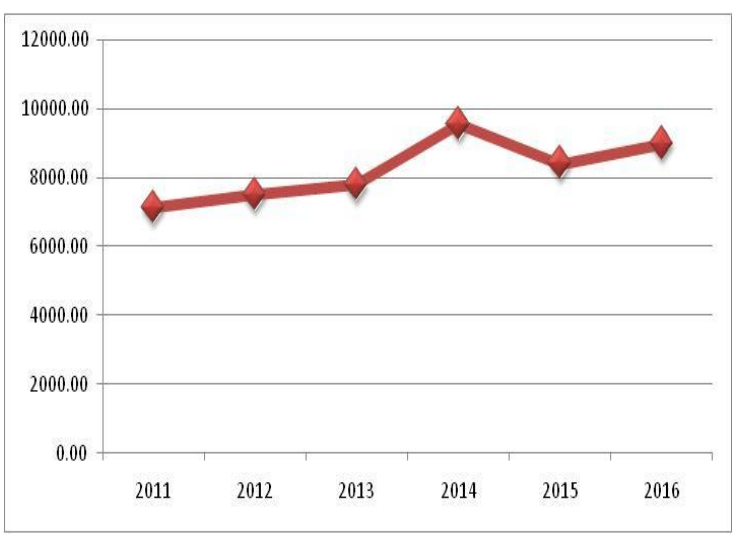

Gambar 2. Perkembangan Rata-Rata Harga Saham
Berdasarkan grafik di atas, perkembangan rata-rata ROA dan NPM dari tahun 2011 sampai 2016 selalu mengalami penurunan. Untuk perkembangan rata-rata ROE dari tahun 2011 sampai 2013 juga mengalami penurunan namun pada tahun 2014 terjadi kenaikan yang sangat signifikan dan tahun 2011-2013 dan pada tahun 2015 dan 2016 ROE kembali mengalami penurunan. Sedangkan rata-rata harga saham dari tahun 2011 sampai 2014 selalu mengalami peningkatan dan tahun 2015 mengalami penurunan dan tahun 2016 kembali mengalami peningkatan walaupun tidak signifikan, peningkatan rata-rata harga saham yang terjadi selama 4 (empat) tahun tersebut disebabkan membaiknya perekonomian Indonesia sehingga memancing dana investasi asing yang besar untuk masuk ke Bursa Efek Indonesia, membaiknya kinerja pasar modal Indonesia, rupiah terus menguat, penurunan harga BBM, penurunan suku bunga sehingga mendongrak pertumbuhan ekonomi domestik, adanya aturan baru dari Bursa Efek Indonesia atas satuan perdagangan dan fraksi perubahan harga saham yang berlaku per 6 Januari 2014, dan momen pelaksanaan Pemilihan Umum (Pemilu) terkait visi dan misi dari para calon Presiden dan Wakil Presiden atas perekonomian domestik.

Fenomena dari pergerakan harga saham yang terjadi pada perusahaan indeks LQ-45 periode 2011-2016 yang sebenarnya justru tidak sesuai dengan teori yang ada bahwa pertumbuhan rasio-rasio keuangan yang baik akan diikuti pula dengan pertumbuhan harga saham (Ang, 1997 dalam Hanry Dwi Purnomo, 2011). Jadi secara teoritis jika kinerja keuangan perusahaan mengalami peningkatan, maka harga saham akan 
merefleksikannya dengan peningkatan harga saham demikian juga sebaliknya. Akan tetapi kenyataan yang terjadi pada perusahaan LQ-45 yang tedaftar di BEl periode 20112016 justru sebaliknya dimana harga saham selalu mengalami peningkatan selama periode pengamatan dan pada saat yang sama rasio-rasio keuangan terutama ROA dan NPM mengalami penurunan.

Return On Assets adalah kemampuan suatu perusahaan (aktiva perusahaan) dengan seluruh modal yang bekerja di dalamnya untuk menghasilkan laba operasi perusahaan (EBIT) atau perbandingan laba usaha dengan modal sendiri dan modal asing yang digunakan untuk menghasilkan laba dan dinyatakan dalam persentase (Irawati, 2012:59). Semakin baik ROA maka tingkat kepercayaan investor untuk berinvestasi pada perusahaan tersebut semakin tinggi. Return on Asset perlu dipertimbangkan oleh investor dalam berinvestasi saham, karena Return on Asset berperan sebagai indikator efisiensi perusahaan dalam menggunakan aset untuk memperoleh laba. Penelitian Husaini, Achmad. (2012), Febriyanto, Feri Citra, dkk (2014), Ika Oktaviani, Dewi Pramita (2015), Rinati (2012) dan Mugi, Anggita, dkk (2014) mendapatkan hasil ROA berpengaruh signifikan terhadap harga saham. Hasil yang berlainan ditemukan oleh Vasta Biqul Khoir, dkk (2013), Hartono, dkk (2009), Murtiningsih, Dwi (2013), Dini dan Indarti (2012) dan Devita Sari, Lola. (2015) menemukan bahwa ROA tidak berpengaruh signifikan terhadap harga saham.

ROE

menunjukkan kemampuan perusahaan dengan menghasilkan laba setelah pajak dengan menggunakan modal sendiri yang dimiliki perusahaan (Sudana,
2011:22). Rasio ini penting bagi pihak pemegang saham untuk mengetahui efektivitas dan efisiensi pengelolaan modal sendiri yang dilakukan oleh pihak manajemen perusahaan. Angka ROE yang semakin tinggi memberikan indikasi bagi para pemegang saham bahwa tingkat pengembalian investasi makin tinggi. Hasil penelitian yang berkaitan dengan ROE dilakukan oleh Devita Sari, Lola. (2015), Febriyanto, Feri Citra, dkk (2014), Hartono, dkk (2009), Ika Oktaviani, Dewi Pramita (2015), Dini dan Indarti (2012) dan Mugi, Anggita., dkk (2014) menemukan bahwa ROE berpengaruh signifikan terhadap harga saham. Namun penelitian ini tidak konsisten dengan penelitian yang dilakukan oleh Murtiningsih, Dwi (2013), Rinati (2012) dan Husaini, Achmad. (2012) menemukan bahwa ROE tidak berpengaruh signifikan terhadap harga saham.

NPM adalah rasio yang mengukur perbandingan pendapatan bersih terhadap penjualan bersih. Menurut Tandelilin (2010:386), semakin besar rasio ini, berarti semakin baik perusahaan dalam menghasilkan laba. Rasio ini memperlihatkan teknik perusahaan dalam mengontrol biaya agar efisien. Dengan laba bersih yang besar, bertambah luas kesempatan bagi perusahaan untuk memperbesar modal usahanya tanpa melalui hutanghutang baru, sehingga pendapatan yang diperoleh menjadi meningkat (Harahap, 2009:304). Hasil penelitian yang berkaitan dengan NPM dilakukan oleh Murtiningsih, Dwi (2013), Devita Sari, Lola. (2015) dan Mugi, Anggita., dkk (2014) menemukan bahwa NPM berpengaruh signifikan terhadap harga saham. Namun Vasta Biqul Khoir, dkk (2013), Husaini, Achmad. (2012), Hartono, dkk (2009), Febriyanto, Feri Citra dkk (2014), Rinati (2012), Dini 
dan Indarti (2012) dan Ika Oktaviani, Dewi Pramita (2015) menemukan hasil berbeda bahwa NPM tidak berpengaruh signifikan terhadap harga saham.

Dari uraian diatas penelitian ini bertujuan mengetahui pengaruh rasio profitabiltas dalam hal ini adalah Rasio ROA, ROE dan NPM Terhadap Harga Saham pada Perusahaan yang terdaftar dalam Indeks LQ-45 di Bursa Efek Indonesia periode 2011-2016 dan akan dianalisa untuk dikaji lebih lanjut mengenai hubungan rasio keuangan terhadap pergerakan harga saham yang dimiliki. Banyaknya teori yang menyatakan bahwa kondisi rasio keuangan yang baik, nantinya akan membawa pengaruh yang positif terhadap kondisi keuangan perusahaan yang juga akan berpengaruh positif terhadap pergerakan harga saham dan adanya perbedaan hasil penelitian tentang rasio-rasio keuangan yang mempengaruhi pergerakan harga saham, maka dalam penelitian ini akan dikaji ulang sehingga apa yang menjadi hasil penelitian nantinya akan mempertegas dan memperkuat teori yang ada, maka penulis memberi judul penelitian ini adalah Analisis Rasio ROA, ROE dan NPM dalam memprediksi Pegerakan Harga Saham (Studi pada Perusahaan yang terdaftar dalam Indeks LQ-45 di Bursa Efek Indonesia periode 2011-2016).

HASIL DAN PEMBAHASAN

Analisis Deskriptif

Tabel 1. Statistik Deskriptif

\begin{tabular}{lrrrrr}
\hline \hline & $N$ & \multicolumn{1}{c}{ Minimum } & Maximum & \multicolumn{1}{c}{ Mean } & Std. Deviation \\
\hline ROA & 144 & -4.75 & 71.51 & 10.6453 & 11.58635 \\
ROE & 144 & -147.20 & 799.10 & 27.2995 & 71.78037 \\
NPM & 144 & -13.68 & 44.03 & 17.2004 & 11.13559 \\
Harga Saham & 144 & 314 & 38800 & 8233.21 & 7956.304 \\
\hline
\end{tabular}

\section{METODE}

Rancangan penelitian yang digunakan dalam penelitian ini adalah penelitian eksplanatori dengan pendekatan analisis kuantitatif.

Sumber Data yang digunakan adalah data sekunder yang diambil dari Indonesian Capital Market Directory (ICMD).

Metode pengumpulan data menggunakan metode dokumentasi. Populasi dalam penelitian ini adalah perusahaan yang sahamnya tergabung dalam indeks LQ-45 sebanyak 45 Perusahaan. Sampel yang diambil sebanyak 24 perusahaan indeks LQ45 dalam kurun waktu 6 tahun (20112016). Teknik sampling yang digunakan adalah metode purposive sampling.

Metode analisis data menggunakan analisis regresi linear berganda dengan terlebih dahulu dilakukan uji asumsi klasik yang meliputi uji normalitas, uji multikolinieritas, uji heteroskedastisitas dan uji autokorelasi. Dengan pengujian hipotesis menggunakan uji signifikansi secara bersama-sama (uji-F) dan uji signifikansi secara parsial (uji t) serta koefisien determinasi (R2).

Sumber : Data primer diolah 2017 
Berdasarkan hasil perhitungan di atas tampak bahwa Return On Asset (ROA) memiliki nilai terendah sebesar $-4,75 \%$ nilai terting i sebesar $71,51 \%$ rata-rata sebesar 10,6453\%. Sedangkan standar deviasi untuk ROA adalah sebesar 11,58635 masih lebih besar jika dibandingkan dengan meannya sebesar 10,6453\%. Dengan demikian dapat dikatakan bahwa simpangan data pada rasio ROA kurang baik.

Rasio ROE memiliki nilai terendah sebesar $-147,20 \%$, nilai tertinggi sebesar $799,10 \%$, rata-rata sebesar 27,2995\%. Sedangkan standar deviasi sebesar 71,58635 masih lebih besar jika dibandingkan dengan mean-nya sebesar 27,2995\%. Dengan demikian dapat dikatakan bahwa simpangan data pada rasio ROE kurang baik.

Rasio NPM memiliki nilai terendah sebesar $-13,68 \%$, nilai tertinggi sebesar 44,03\%, rata-rata sebesar 17,2004\%. Sedangkan standar deviasi sebesar 11,13559 masih lebih kecil jika dibandingkan dengan mean-nya sebesar 17,2004\%. Dengan demikian dapat dikatakan bahwa simpangan data pada rasio NPM relatif baik.

Harga saham memiliki nilai terendah sebesar 314, nilai tertinggi sebesar 38800, rata-rata sebesar 8233,21 . Sedangkan standar deviasi sebesar 7956,304 masih lebih kecil jika dibandingkan dengan mean-nya sebesar 8233,21. Dengan demikian dapat dikatakan bahwa simpangan data pada harga saham relatif baik.

\section{Analisis Inferensial Uji Asumsi Klasik} Tabel 2. Hasil Pengujian Normalitas

\begin{tabular}{ccc}
\hline \hline Variabel & $\begin{array}{c}\text { Unstandardized } \\
\text { Residual }\end{array}$ & $\begin{array}{c}\text { Nilai } \\
\text { Standarisasi }\end{array}$ \\
\hline $\mathrm{X}_{2}, \mathrm{X}_{2}, \mathrm{X}_{2} \rightarrow \mathrm{Y}$ & 0,472 & 0,05 \\
\hline \multicolumn{2}{c}{ Sumber : Data primer yang diolah 2017} &
\end{tabular}

Berdasarkan hasil uji normalitas data menggunakan One Sample Kolmogorov Smirnov Test, sebagaimana tersaji pada tabel diatas dapat disimpulkan bahwa semua variabel memiliki data normal, hal tersebut dikarenakan data tersebut memiliki Asymp. Sig > (a) 0,05.

Tabel 3. Hasil Uji Multikolinearitas

\begin{tabular}{lcc}
\hline \hline Variabel bebas & Tolerance & VIF \\
\hline ROA $\left(X_{1}\right)$ & 0.700 & 1.429 \\
$\operatorname{ROE}\left(X_{2}\right)$ & 0.590 & 1.696 \\
NPM $\left(X_{3}\right)$ & 0.811 & 1.233 \\
\hline
\end{tabular}

Sumber : Data primer yang diolah 2017

Berdasarkan hasil uji multikolinearitas diperoleh nilai Variance Inflation Factor (VIF) pada semua variabel independen berada tidak jauh dari nilai 1 atau lebih kecil dari 10 dan angka tolerance mendekati 1 maka dapat diambil kesimpulan bahwa tidak terdapat gejala multikolinearitas, sehingga regresi sah untuk digunakan.

Tabel 4. Hasil Pengujian Heterokedastisitas

\begin{tabular}{cc}
\hline $\begin{array}{c}\text { Variabel } \\
\text { Independen }\end{array}$ & $\begin{array}{c}\text { Unstandardized Residual } \\
\text { Sig. (2-Tailed) }\end{array}$ \\
\hline $\operatorname{ROA}\left(\mathrm{X}_{1}\right)$ & 0.490 \\
$\mathrm{ROE}\left(\mathrm{X}_{2}\right)$ & 0.747 \\
$\mathrm{NPM}\left(\mathrm{X}_{3}\right)$ & 0.093 \\
\hline
\end{tabular}

Sumber : Data primer yang diolah 2017

Dari hasil uji Glejser menunjukkan bahwa masing-masing variabel tersebut tidak memiliki pengaruh secara signifikan sehingga berarti tidak terjadi heteroskedastisitas atau nilai signifikan untuk ketiga variable lebih besar dari 0,05. Karena signifikansi lebih besar daripada 0,05, maka dapat disimpulkan bahwa tidak terjadi problem heteroskedasitas. 
Tabel 5. Hasil Pengujian Autokorelasi

\begin{tabular}{cc}
\hline \hline Model & Nilai Durbin-Watson \\
\hline $\mathrm{X}_{2}, \mathrm{X}_{2}, \mathrm{X}_{2} \rightarrow \mathrm{Y}$ & 0,785 \\
\hline Sumber:
\end{tabular}

Sumber : Data primer yang diolah 2017

Berdasarkan tabel diatas menunjukkan nilai Durbin-Watson sebesar 0,785. Karena angka D-W berada antara -2 sampai +2 , hal ini berarti tidak terdapat masalah autokorelasi. Jadi dapat disimpulkan dalam model regresi tidak ada korelasi antara kesalahan pengganggu pada periode $t$ dengan kesalahan pengggangu pada periode $\mathrm{t}-1$.

\section{Uji Regresi Linear Berganda}

Tabel 6. Rekapitulasi Hasil Regresi Linear Berganda

\begin{tabular}{|c|c|c|c|c|c|}
\hline $\begin{array}{c}\text { Variabel } \\
\text { Independen }\end{array}$ & $\begin{array}{l}\text { Koefisien } \\
\text { Regresi } \beta\end{array}$ & Beta & t-hitung & Sig. & Kesimpulan \\
\hline $\mathrm{ROA}\left(\mathrm{X}_{1}\right)$ & 0.015 & 0.368 & 4.594 & 0.000 & Signifikan \\
\hline $\operatorname{ROE}\left(X_{2}\right)$ & 0.121 & 0.120 & 1.370 & 0.173 & Tidak Signifikan \\
\hline $\operatorname{NPM}\left(X_{3}\right)$ & 0.013 & 0.315 & 4.230 & 0.000 & Signifikan \\
\hline $\begin{array}{l}\text { Constant } \\
\text { Korelasi }(R) \\
\text { Adjusted R Square } \\
\left(R^{2}\right) \\
\text { Fhitung } \\
\text { Ftabel } \\
\text { ttabel } \\
\text { Sig.F }\end{array}$ & $\begin{array}{l}: 3,162 \\
: 0,609 \\
: 0,357 \\
: 27,507 \\
: 2,669 \\
: 1,977 \\
: 0,000\end{array}$ & & & & \\
\hline
\end{tabular}

Sumber : Data primer yang diolah 2017

Hasil perhitungan pada tabel diperoleh nilai persamaan regresi liner berganda sebagai berikut: $Y=3,164+$ $0,015 X_{1}+0,121 X_{2}+0,013 X_{3}$

Nilai konstanta sebesar 3,164 berarti setiap perubahan atau pengurangan satu satuan ROA, ROE dan NPM akan merubah atau mengurangi harga saham sebesar 3,164. Nilai koefisien regresi $X_{1}$ sebesar 0,015 berarti jika ROA naik sebesar satu satuan maka harga saham juga naik sebesar 0,015 dengan ketentuan $\mathrm{X}_{2}$ dan $\mathrm{X}_{3}$ konstan. Nilai koefisien regresi $X_{2}$ sebesar 0,121 berarti jika ROE naik sebesar satu satuan maka harga saham naik sebesar 0,121 dengan ketentuan $X_{1}$ dan $X_{3}$ konstan. Nilai koefisien regresi $\mathrm{X}_{3}$ sebesar 0,013 berarti jika NPM naik sebesar satu satuan maka harga saham naik sebesar 0,013 dengan ketentuan $\mathrm{X}_{1}$ dan $\mathrm{X}_{2}$ konstan.

\section{Uji Koefisien Determinasi $\left(\mathbf{R}^{2}\right)$}

Dari hasil uji koefisien determinasi diperoleh nilai sebesar 0,357, hal ini berarti ROA, ROE dan NPM memberikan sumbangan sebesar $35,7 \%$ terhadap harga saham pada Perusahaan Indeks LQ-45 di Bursa Efek Indonesia periode 2011-2016 sedangkan sisanya $64,3 \%$ dipengaruhi oleh faktor lain yang tidak diteliti.

\section{Pembahasan}

Pengaruh ROA, ROE dan NPM Terhadap Pergerakan Harga Saham

Berdasarkan uji secara simultan diperoleh nilai $F_{\text {hitung sebesar } 27,507}$ lebih besar dari $F_{\text {tabel }}(2,669)$, hal ini juga diperkuat dengan nilai taraf signifikansi sebesar 0,000 atau signifikansi yang diperoleh lebih kecil dari $\alpha=0,05$, maka dapat disimpulkan bahwa ROA, ROE dan NPM secara bersama-sama berpengaruh positif dan signifikan terhadap harga saham. 
Hasil penilaian ini berarti dalam menilai saham suatu perusahaan, calon investor dapat menggunakan ketiga variabel tersebut sebagai dasar pembuatan keputusan investasi saham. Ketiga variabel ini juga dimanfaatkan sebagai acuan dalam menilai dan memprediksi harga saham emiten. Hasil ini juga dapat dimanfaatkan perusahaan sebagai acuan untuk terus mengoptimalkan kinerjanya agar nilai perusahaan meningkat.

Hasil penelitian ini sejalan dengan penelitian yang dilakukan oleh Febriyanto, Feri Citra dkk (2014), Rinati (2012) dan Dini, dkk (2012) mendapatkan hasil bahwa secara bersama-sama ROA, ROE dan NPM berpengaruh signifikan terhadap harga saham.

\section{Pengaruh ROA Terhadap Pergerakan Harga Saham}

Berdasarkan hasil analisi regresi linier berganda diperoleh variabel ROA memiliki koefisien regresi yang menunjukkan nilai sebesar 0,015. Koefisien regresi ini menunjukkan bahwa apabila terdapat kenaikan 1 kali pada variabel $X_{1}$ dan variabel yang lain dianggap tetap atau sama dengan 0 , maka akan terjadi peningkatan pada variabel $Y$ sebesar 0,015 . Dari uji $t$ didapat hasil bahwa variabel bebas ROA berpengaruh secara signifikan terhadap harga saham. Hal tersebut dapat diketahui dari statistik uji $t$ sebesar 4,594 dengan signifikan sebesar 0,000 . Nilai statistik uji thitung tersebut lebih besar daripada tabel $(4,594>1,977)$ dan nilai signifikan lebih kecil daripada $\alpha=0,05$.

(ROA) dalam Return On Asset berpengaruh positif secara signifikan. Variabel Return On Asset (ROA) yang positif menunjukkan bahwa ada peningkatan laba dibandingkan dengan aset perusahaan. Hal itu menunjukkan bahwa perusahaan semakin baik dalam pengelolaan asetnya dalam menghasilkan laba merupakan informasi yang baik sehingga akan menarik minat para investor untuk melakukan transaksi saham. Semakin besar permintaan saham dibandingkan penawaran saham maka dapat meningkatkan harga saham.

Hasil penelitian ini sejalan dengan penelitian yang dilakukan oleh Husaini, Achmad. (2012), Febriyanto, Feri Citra, dkk (2014), Ika Oktaviani, Dewi Pramita (2015), Rinati (2012) dan Mugi, Anggita, dkk (2014) mendapatkan hasil ROA berpengaruh signifikan terhadap harga saham. Hasil yang berlainan ditemukan oleh Vasta Biqul Khoir, dkk (2013), Hartono, dkk (2009), Murtiningsih, Dwi (2013), Dini dan Indarti (2012) dan Devita Sari, Lola. (2015) menemukan bahwa ROA tidak berpengaruh signifikan terhadap harga saham.

\section{Pengaruh ROE Terhadap Pergerakan Harga Saham}

Berdasarkan hasil analisi regresi linier berganda diperoleh variabel ROE memiliki koefisien regresi yang menunjukkan nilai sebesar 0,121. Koefisien regresi ini menunjukkan bahwa apabila terdapat kenaikan 1 kali pada variabel $X_{2}$ dan variabel yang lain dianggap tetap atau sama dengan 0 , maka akan terjadi peningkatan pada variabel $\mathrm{Y}$ sebesar 0,121 . Dari uji $t$ didapat hasil bahwa variabel bebas ROE berpengaruh tidak signifikan terhadap harga saham. Hal tersebut dapat diketahui dari statistik uji $t$ sebesar 1,370 dengan signifikan sebesar 0,173 . Nilai statistik uji thitung tersebut lebih kecil daripada $t_{\text {tabel }}$ $(1,370<1,977)$ dan nilai signifikan lebih besar daripada $\alpha=0,05$. 
Variabel Return On Equity (ROE) dalam penelitian ini tidak berpengaruh secara signifikan terhadap harga saham. Hal ini terjadi karena ROE hanya menggambarkan besarnya pengembalian atas investasi yang dilakukan pemegang saham biasa, namun tidak menggambarkan prospek perusahaan sehingga pasar tidak terlalu merespon dengan besar kecilnya ROE sebagai pertimbangan investasi yang akan dilakukan investor.

Hasil penelitian ini sejalan dengan penelitian yang dilakukan oleh Devita Sari, Lola. (2015), Febriyanto, Feri Citra, dkk (2014), Hartono, dkk (2009), Ika Oktaviani, Dewi Pramita (2015), Dini dan Indarti (2012) dan Mugi, Anggita., dkk (2014) menemukan bahwa ROE berpengaruh signifikan terhadap harga saham. Namun penelitian ini tidak konsisten dengan penelitian yang dilakukan oleh Murtiningsih, Dwi (2013), Rinati (2012) dan Husaini, Achmad. (2012) menemukan bahwa ROE tidak berpengaruh signifikan terhadap harga saham.

\section{Pengaruh NPM Terhadap Pergerakan Harga Saham \\ Berdasarkan hasil analisi} regresi linier berganda diperoleh variabel NPM memiliki koefisien regresi yang menunjukkan nilai sebesar 0,013. Koefisien regresi ini menunjukkan bahwa apabila terdapat kenaikan 1 kali pada variabel $X_{3}$ dan variabel yang lain dianggap tetap atau sama dengan 0 , maka akan terjadi peningkatan pada variabel $\mathrm{Y}$ sebesar 0,013 . Dari uji t didapat hasil bahwa variabel bebas NPM berpengaruh secara signifikan terhadap harga saham. Hal tersebut dapat diketahui dari statistik uji t sebesar 4,230 dengan signifikan sebesar 0,000 . Nilai statistik uji thitung tersebut lebih besar daripada $t_{\text {tabel }}(4,230>1,977)$ dan nilai signifikan lebih kecil daripada $\alpha=0,05$.

Variabel Net Profit Margin

(NPM) dalam penelitian ini berpengaruh positif dan signifikan terhadap harga saham. Hal tersebut menunjukan bahwa perusahaan dengan kemampuan perusahaan menghasilkan pendapatan bersihnya terhadap total penjualan yang dicapai mempengaruhi investor untuk masuk sehingga sahamnya di pasar bursa banyak diburu pembeli. Peningkatan permintaan terhadap saham dapat mempengaruhi harga saham tersebut.

Hasil penelitian ini sejalan dengan penelitian yang dilakukan oleh Murtiningsih, Dwi (2013), Devita Sari, Lola. (2015) dan Mugi, Anggita., dkk (2014) menemukan bahwa NPM berpengaruh signifikan terhadap harga saham. Namun Vasta Biqul Khoir, dkk (2013), Husaini, Achmad. (2012), Hartono, dkk (2009), Febriyanto, Feri Citra dkk (2014), Rinati (2012), Dini dan Indarti (2012) dan Ika Oktaviani, Dewi Pramita (2015) menemukan hasil berbeda bahwa NPM tidak berpengaruh signifikan terhadap harga saham.

\section{Variabel yang Berpengaruh Dominan Terhadap Harga Saham \\ Dari hasil regresi diatas} apabila dilihat pada Standardized coefficients, diketahui bahwa nilai koefisien regresi masing-masing variabel independen secara parsial yang mencerminkan besarnya pengaruh atau kontribusi terhadap variabel dependen. Nilai koefisien Beta variabel ROA $\left(X_{1}\right)$ sebesar 0,368, variabel $\operatorname{ROE}\left(X_{2}\right)$ sebesar 0,120 , dan variabel NPM $\left(X_{3}\right)$ sebesar 0,315.

Berdasarkan pengujian t-test hanya variabel ROA dan NPM yang secara parsial berpengaruh signifikan terhadap harga saham. Dalam menentukan variabel independen yang 
dominan berpengaruh terhadap variabel terikat maka akan dilihat nilai standar beta variabel ROA dan NPM. Hasil perhitungan menunjukkan bahwa nilai beta variabel ROA sebesar 0,368 dan NPM sebesar 0,315. Dengan demikian ROA ditentukan sebagai variabel independen yang secara parsial berpengaruh dominan terhadap harga saham. Pengaruh dominan ROA terhadap harga saham mengindikasikan tingkat return yang tinggi yang diperoleh emiten yang menyebabkan harga saham naik.

\section{SIMPULAN}

Dari hasil uji secara simultan dengan uji $F$ dapat disimpulkan bahwa kinerja keuangan perusahaan yang diukur dari ROA, ROE, dan NPM mempunyai pengaruh terhadap harga saham.

Dari hasil uji secara parsial dengan uji t, dapat disimpulkan bahwa secara parsial variabel ROA dan NPM berpengaruh secara signifikan terhadap harga saham, sedangkan variabel ROE tidak berpengaruh secara signifikan terhadap harga saham.

Dari hasil uji t diperoleh hasil bahwa ROA $\left(X_{1}\right)$ mempunyai pengaruh yang paling dominan terhadap harga saham pada perusahaan yang termasuk dalam indeks LQ 45.

\section{DAFTAR RUJUKAN}

Devita Sari, Lola. 2015. Pengaruh Ratio Profitabilitas Terhadap Harga Saham Pada Bank Milik Pemerintah (BUMN) Yang Terdaftar di Bursa Efek Indonesia ( $\mathrm{BEI}$ ) Periode 2007-2014. Jom FISIP Vol 3 No.2 Oktober 2015 (online). Diakses, 21 September 2016.

Dini, Astri Wulan dan Indarti, lin. 2012. Pengaruh Net Profit Margin
(NPM), Return On Assets (ROA), dan Return On Equity (ROE) terhadap Harga Saham yang Terdaftar Dalam Indeks Emiten LQ45 tahun 20082010. Jurnal Kajian Akuntansi dan Bisnis. Vol. 1, No. 1 (online). Diakses, 12 Oktober 2017.

Febriyanto, Feri Citra \& Nurwiyanta. 2014. Pengaruh Return On Equity (ROE), Return On Assets (ROA), Dan Net Profit Margin (NPM) Terhadap Harga Saham Pada Sektor Real Estate and Property di Bursa Efek Indonesia Periode 20082011. Fakultas Ekonomi Universitas Janabadra Yogyakarta. Efektif Jurnal Bisnis Dan Ekonom Vol. 5, No 1, Juni 2014, 19 - 30 (online). Diakses, 21 September 2016.

Hartono \& Parulian Sihotang, Raymundus. 2009. Analisis Hubungan Profitabilitas Dengan Pergerakan Harga Saham Pada Sektor Usaha Perbankan di Bursa Efek Indonesia. Journal Of Applied Finance And Accounting 2 (2) 51 - 66 (online). Diakses, 21 September 2016.

Husaini, Achmad. 2012. Pengaruh Variabel Return On Assets, Return On Equity, Net Profit Margin Dan Earning Per Share Terhadap Harga Saham Perusahaan, Jurusan Administrasi Bisnis FIA UB. Jurnal Profit, Volume 6, Nomor 1, Juni 2012 (online). Diakses, 21 September 2016.

Irawaty, Ester Farida. 2009. Analisis Faktor Fundamental Terhadap Harga Saham Menggunakan Rasio Profitabilitas Pada Industri Properti di Bursa Efek Indonesia. Skripsi Akuntansi 
Universitas Sumatera Utara, Medan (online). Diakses, 21 September 2016.

Mugi, Anggita., Kohar Irwanto, Abdul \& Permanasari, Yusrina. 2014. Analisis Pengaruh Rasio Profitabilitas Dan Economic Value Added Terhadap Harga Saham Pada Sub Sektor Industri Semen Yang Terdaftar di Bursa Efek Indonesia. Departemen Manajemen, Fakultas Ekonomi dan Manajemen Institut Pertanian Bogor. Jurnal Manajemen dan Organisasi Vol V, No 2, Agustus 2014 (online). Diakses, 21 September 2016.

Murtiningsih, Dwi. 2013. Pengaruh ROA, ROE, NPM, EPS, dan DER Terhadap Tingkat Harga Saham (Pada Perusahaan Food and Baverages di BEI Tahun 2008-2010). Fakultas Ekonomi Universitas Semarang. Jurnal Dinamika Manajemen Vol. 2 No. 5 Januari 2013 (online). Diakses, 21 September 2016.

Oktaviani, Dewi Pramita Ika. 2015. Pengaruh Return On Asset (Roa), Return On Equity (ROE), Net Profit Margin (NPM) And Debt To Equity Ratio (DER) Terhadap Harga Saham (Studi Empiris Pada Perusahaan Manufaktur Yang Terdaftar di Bursa Efek Indonesia). Jurusan Akuntansi, Fakultas Ekonomi, Universitas Jember (UNEJ). Artikel IImiah Mahasiswa 2015 (online). Diakses, 21 September 2016.

Purnomo, Hanry Dwi. 2007. Pengaruh Kinerja Keuangan Terhadap Harga Saham Perusahaan Perbankan yang Terdaftar di Bursa Efek Jakara Tahun 2003-2005. (dipublikasikan)

Jurusan Akuntansi, Fakultas Ekonomi, Universitas Negeri Semarang. (online). Diakses, 21 September 2016.

Rinati, Ina. 2008. Pengaruh Net Profit Margin (NPM), Return On Assets (ROA) dan Return On Equity (ROE) terhadap Harga Saham pada Perusahaan yang Tercantum Indeks LQ45 tahun 2004-2008. Jurnal Ekonomi dan Manajemen. Universitas Gunadarma (online). https://scholar.google.co.id/sch olar. Diakses, 12 Oktober 2017.

Sudana, I Made. 2011. Manajemen Keuangan Perusahaan Teori \& Praktek. Penerbit Erlangga : Jakarta.

Tandelilin, Eduardus. 2010. Portofolio dan Investasi: Teori dan Aplikasi. Kanisius Yogyakarta. 